\title{
ANALISIS IMPLEMENTASI PENDIDIKAN KARAKTER DALAM KONTEKS PENDIDIKAN UMUM MENURUT KAJIAN TEORI KRITIS JURGEN HUBERMAS
}

\author{
Asep Dahliyana, Ahmad Syamsu Rizal, Encep Syarief Nurdin \\ Departemen Pendidikan Umum, Universitas Pendidikan Indonesia, \\ Jl. Dr. Setiabudhi No. 229, Bandung 40154 \\ E-mail: asep_dahly@upi.edu
}

\begin{abstract}
Character education is not a new thing in Indonesia. However, the implementation of character education in the school results is not very enjoyable. The approach that is used to be compulsory courses in the context of general education that is processed through a lecture bench is less satisfactory. The approach used to obtain data is the mix method through survey techniques and interviews. The results showed that (1) the implementation of character education in Indonesia was only at the level of 2.65; (2) The implementation of character education on the development of students ' character can not be optimal because of lack of training to educators; (3) The implementation of character education in the context of general education is still weak, because general education is still overlapping with the realm of other disciplines.
\end{abstract}

Keywords: Character Education, General Education, Critical Theory

\section{PENDAHULUAN}

Dokumen autentik yang tidak terbantahkan bahwa pembangunan bangsa dan pembangunan karakter merupakan komitmen bangsa Indonesia yang harus diwujudkan sepanjang hayat (Budimansyah, 2009). Pembangunan karakter merupakan upaya perwujudan amanat Pancasila dan Pembukaan UUD NRI 1945 yang dilatarbelakangi oleh realita permasalahan kebangsaan yang berkembang saat ini baik secara eksternal maupun internal. Dengan konkret, hasil Amandemen Undang-Undang Dasar Negara Republik Indonesia Tahun 1945 ke IV (empat) pada pasal 31 ayat (3) berbunyi, "pemerintah mengusahakan dan menyelenggarakan satu sistem pendidikan nasional yang meningkatkan keimanan dan ketakwaan serta akhlak mulia dalam rangka mencerdaskan kehidupan bangsa yang diatur dengan undang-undang”.

Semangat untuk menjadi bangsa yang berkarakter ditegaskan oleh Soekarno dengan mencanangkan nation and character building dalam rangka membangun dan mengembangkan karakter bangsa Indonesia guna mewujudkan cita-cita bangsa, yaitu masyarakat yang adil dan makmur berdasarkan Pancasila (Direktorat Ketenagaan, Direktorat Jenderal Pendidikan Tinggi, 2010). Langkah membangun kebangsaan dan karakter yang dilaksanakan pada awal proklamasi kemerdekaan (Orde Lama) diketahui dari tujuan pendidikan nasional yang bertujuan untuk membentuk warga negara yang demokratis serta membangun karakter peserta didik yang cinta pada tanah air dan punya jiwa patriot yang tinggi. Ketika Orde Baru tujuan pendidikan nasional berubah yaitu untuk membentuk manusia pancasila sebagai manusia pembangunan yang tinggi mutunya. Memasuki era reformasi tujuan pendidikan nasional menjadi membentuk watak yang beriman dan bertakwa kepada Tuhan Yang Maha 
Esa, cakap, kreatif, mandiri, dan bertanggung jawab.

Dikukuhkannya pendidikan karakter sebagai misi pertama dari delapan misi guna mewujudkan visi pembangunan nasional, sebagaimana tercantum dalam Rencana Pembangunan Jangka Panjang Nasional tahun 20052025 (Undang-Undang Republik Indonesia Nomor 17 Tahun 2007) yaitu terwujudnya karakter bangsa yang tangguh dan sebagainya menjadi angin segar dalam rangka pencapaian cita-cita negara tersebut. Kebijakan Nasional Pembangunan Karakter Bangsa ini disusun secara bersama-sama oleh berbagai kementerian, lembaga nonkementerian dan lembaga non-pemerintah yang terkait, antara lain Kwartir Nasional Gerakan Pramuka dan Yayasan Jati Diri Bangsa. Dalam penyusunan Kebijakan Nasional ini juga menggali masukan dari para pakar, praktisi, tokoh masyarakat, pemuka agama, budayawan, dan berbagai pihak yang memiliki kepedulian terhadap pembangunan karakter bangsa. Untuk itu telah dilakukan sarasehan yang bersifat nasional pada tanggal 14 Januari 2010 dengan dihadiri lebih dari 200 orang pakar, praktisi, pemerhati dan diikuti dengan kegiatan diskusi maupun sarasehan lainnya di berbagai wilayah Indonesia (Pemerintah Republik Indonesia, 2010).

Namun dalam konteks
pendidikan, pendidikan karakter yang dipraktikkan di persekolahan selama ini dampaknya masih jauh dari harapan (Raka, 2011; Budimansyah, 2010). Terdapat paling tidak tujuh masalah pokok yang melanda dunia pendidikan Indonesia sebagai akar timbulnya krisis moralitas dan moral, yaitu (1) arah pendidikan telah kehilangan obyektifitasnya; (2) proses pendewasaan diri tidak berlangsung semestinya di lingkungan sekolah; (3) proses pendidikan sekolah sangat membelenggu ruang gerak kreatifitas baik peserta didik maupun guru; (4) beban kurikulum yang terlampau berat dan cenderung diorientasikan pada pengembangan kognitif semata; (5) kalaupun ada materi yang dapat menumbuhkan rasa afeksi seperti mata pelajaran agama dan pendidikan moral yang sekarang dikenal sebagai Pendidikan Kewarganegaraan (Pendidikan Kewarganegaraan); (6) pada saat yang sama para peserta didik dihadapkan pada nilai-nilai yang sering bertolak belakang (contradictionary set of values); dan (7) minimnya contoh teladan (living moral exemplary-uswatun hasanah) bagi peserta didik dalam kehidupannya (Azra, 2001). Selain itu, generasi muda telah kehilangan pegangan dan keteladanan dalam meniru perilaku etis. Mereka kehilangan model orang dewasa yang dapat digugu dan ditiru (Zuriah, 2007). Sehingga akhir dari perilaku masyarakat Indonesia saat ini, yaitu (1) melemahnya semangat keIndonesia-an, (2) praktik korupsi yang meluas, (3) kurangnya disiplin bangsa, (4) sulit mengakui perbedaan, (5) kurangnya rasa kritis, dan (6) munafik, tidak sesuainya ucapan dan kelakuan (Raka, 2011). Akhirnya muncul perilakuperilaku negatif, diantaranya tawuran antar pelajar/mahasiswa, kecenderungan memakai narkoba pada sebagian pelajar, perilaku seks bebas, rendahnya etos belajar, perilaku hedonisme dan konsumtif, kurangnya disiplin dan rasa hormat serta kesantunan, pudarnya rasa nasionalisme, dan yang paling memalukan adalah merebaknya kebiasaan plagiarisme dan mencontek waktu ujian (Bahrun, 2012).

Dalam rangka menyelesaikan masalah tersebut, pemerintah telah mengeluarkan kebijakan berupa pengimplementasian pendidikan karakter. Berhubungan dengan eksistensi Pendidikan Umum, pendidikan karakter bukan pula sesuatu yang asing, sebab "General education as cultural movement and curricular structure (Jencks \& Riesman, 1968; Miller, 1988) yang tertanam dalam budaya institusi (Awbrey, 2005). Untuk menghadapi semua masalah 
tersebut, lembaga-lembaga pendidikan tinggi harus mempromosikan pengembangan hasil pendidikan umum sebagai pelengkap dan saling memperkuat untuk memenuhi berbagai persyaratan dari peradaban kontemporer (Aloi, Gardner, dan Lusher, 2003). Dalam rangkat menganalisis pelaksanaan pendidikan karakter dalam ranah pendidikan umum, penulis berupaya untuk mengkajinya melalui pisau analisis teori yang dikemukakan oleh Jurgen Habermas.

\section{METODE}

Penelitian ini menggunakan dua pendekatan, kuantitatif dan kualitatif dengan pola "the dominant-less dominat design". Bagian pertama dalam penelitian ini menggunakan pendekatan kuantitatif, yakni melalui metode survey. Pendekatan kuantitatif dijadikan sebagai pendekatan yang dominan dalam penelitian ini karena tujuan penelitian untuk mengukur banyak variabel, mengetes hipotesis, dan membuat kesimpulan dari pertanyaanpertanyaan mengenai perilaku, pengalaman, atau karakteristik dari suatu fenomena.

Populasi dalam penelitian ini mahasiswa Sekolah Pascasarjana di Universitas Pendidikan Indonesia jenjang doktoral yang menempuh program studi Pendidikan Umum dan Karakter. Sementara sampel dalam penelitian ini berjumlah 21 orang yang terdiri dari 16 dosen perguruan tinggi negeri dan swasta, 2 orang guru, dan 3 orang dari unsur dinas terdiri dari angkatan 2014-2017 yang berasal dari. Sementara, unsur mahasiswa yang diajar oleh mahasiswa program doktor Pendidikan Umum, berjumlah 105 mahasiswa.

Instrumen pengumpulan data yang dilakukan yaitu dengan suatu instrumen pengukuran yang kredibel yang memenuhi syarat validitas dan reliabilitas. Suatu instrumen memenuhi syarat validitas jika dapat mengukur apa yang seharusnya diukur. Sementara reliabilitas menunjuk pada konsistensi, akurasi, dan stabilitas nilai hasil skala pengukuran. Instrumen yang digunakan dalam penelitian ini adalah kuesioner dan pedoman wawancara. Khusus untuk survey, instrumen yang digunakan yaitu mengadopsi dari Pusat Analisis dan Sinkronisasi Sekretariat Jenderal Kementerian Pendidikan dan Kebudayaan tahun 2017.

\section{HASIL DAN PEMBAHASAN Hasil}

Berdasarkan hasil perhitungan kuesioner, didapatkan gambaran bahwa secara umum, pengimplementasian pendidikan karakter di Indonesia masih berada pada tataran baru terlihat di lingkungan institusi belum pada tahap pembiasaan apalagi sampai menjadi budaya. Hal tersebut dapat dilihat dari hasil perhitungan yang memperoleh nilai 2,65 yang dalam instrumen penilaian penguatan pendidikan karakter yang dikembangkan Pusat Analisis dan Sinkronisasi Kebijakan Sekreatariat Jenderal Kementeraian Pendidikan dan Kebudayaan baru mendapat nilai $\mathrm{C}$ atau sudah mulai terlihat di lingkungan institusi. Adapun nilai 2,65 tersebut diperoleh dari sepuluh aspek penilaian sebagai berikut;

1. nilai asesmen awal mendapatkan nilai 2,68 ;

2. nilai sosialsiasi karakter pada pemangku kebijakan mendapatkan nilai 2,49 ;

3. nilai visi, misi, dan perumusan pendidikan karakter mendapatkan nilai 2,90 ;

4. nilai desain pendidikan karakter yang terdapat pada institusi mendapatkan nilai 2,60 ;

5. nilai desain program pengimplementasian pendidikan karakter mendapatkan nilai 2,71 ;

6. nilai pendidikan karakter berbasis kelas mendapatkan nilai 2,89; 
7. nilai pengembangan budaya sekolah/kampus mendapatkan nilai 2,86 ;

8. nilai partisipasi masyarakat dalam pengimplementasian pendidikan karakter mendapatkan nailai 2,19;

9. nilai implementasi nilai-nilai utama mendapatkan nilai 2,89 ;

10. nilai evaluasi pendidikan karakter mendapatkan nilai 2,28.

Hasil perhitungan tersebut diperkuat dengan hasil wawancara yang dilakukan kepada mahasiswa program doktor Pendidikan Umum dan Karakter SPs UPI yang notabene berprofesi sebagai dosen, guru, dan kedinasan. Dari hasil wawancara tersebut diperoleh gambaran secara umum dari 21 orang narasumber yang mengungkapkan bahwa budaya yang dikembangkan dilembaganya tersebut ada, baik yang diambil dari motto yang dikeluarkan oleh lembaga misalnya Universitas Pendidikan Indonesia seperti edukatif, ilmiah dan religious. Selain itu, terdapat pula lembaga, yang hanya mengaitkan budaya lewat kegiatan mingguan di mana setiap jumat pagi digiatkan bersih-bersih kampus dilanjutkan dengan olah raga dan setelah shalat jumat diadakan pengajian. Selain itu, setiap minggu ada kegiatan spiritual untuk non-muslim.

Penuturan berbeda disampaikan oleh beberapa respinden yang menjelaskan bahwa asset budaya yang dikembangkan di institusinya berasal dari budaya yang turun temurun dilakukan oleh penduduk Minahasa dalam bergotong royong yaitu budaya mapalus. Selain itu, terdapat pula budaya yang dikembangkan dari agama. Budaya tersebut ditopang dengan keunikan insitusi yang dapat dijadikan nilai-nilai utama pengimplementasian pendidikan karakter. Di Universitas Pendidikan Indonesia misalnya, untuk menopang pembinaan karakter mahasiswa dilakukan salah satunya dengan keberadaan Islamic Tutorial Centre. Sementara di insitusi lain dikembangkan dengan cara yang berbeda, antara lain dengan mengeluarkan kebijakan, memadukan budaya, pengembangan kurikulum mata kuliah titipan institusi dalam hal ini pesantren, dan cara bimbingan informasi dan penyuluhan.

Program pendidikan karakter yang sudah ada pada institusi memiliki kadar yang berbeda. Pada salah satu perguruan tinggi negeri, program pendidikan karakter bersatu dengan perkuliahan, di mana mahasiswa yang mengikuti mata kuliah PAI/SPAI harus mengikuti program tutorial. Selain itu, terdapat pula dengan mata kuliah khusus titipan. Beberapa penuturan berbeda, sebab program pendidikan karakter dikembangkan melalui kegiatan intrakurikuler dan ekstrakurikuler meski masih terdapat beberapa kelemahan. Sementara itu, temuan yang menarik yaitu adanya character building development centre yang dikembangkan di BINUS sebagai program pendidikan karakter. Namun, secara umum langkah pendidikan karakter sudah dilaksanakan melalui penyelenggaraan pendidikan umum di perguruan tinggi.

Dengan memperhatikan hasil perhitungan kuesioner dan wawancara, pengimpementasian pendidikan karakter di Indonesia sesungguhnya dapat dilakukan dengan baik, meski terdapat beberapa masalah dikarena sumber daya manusia yang kurang peduli terhadap karakter. Adapun hal lain yang perlu disinggung yaitu masih terbatasnya dana dalam penguatan pendidikan karakter di lembaga/instansi kerja.

\section{Pembahasan}

Wacana akademik mengenai pendidikan karakter di Indonesia semakin ramai dibahas sejak dicanangkannya gerakan pendidikan karakter tanggal 2 Mei 2010. Pada 2 Mei 2010, bertepatan dengan peringatan Hari Pendidikan Nasional (Kaimuddin, 2014). Dalam pendidikan karakter, hal penting untuk dipertanyakan adalah nilai-nilai moral 
manakah yang ingin diajarkan. Pertanyaan demikian membawa perdebatan pada wilayah etika normatif yakni prinsip dan norma moral manakah yang sehat yang dapat dijadikan acuan dan dasar pertangungjawaban rasional bagi penilaian dan putusan moral (Sudarminta, 1997). Hal tersebut dapat dilihat dari berbagai hasil wawancara yang menggambarkan bahwa nilai-nilai moral yang dikembangkan sesuai dengan latar belakang lembaga masing-masing.

Terhadap masalah ini terdapat dua kelompok pendapat yang berbeda. Satu kubu berpendapat bahwa kebenaran moral itu relatif (moral relativism), oleh karena moral baik dan buruk bergantung pada bagaimana individu mendefinisikan. Berdasar teori ini, prinsip moral baik yang berasal dari agama, budaya dan gagasan sosial politik adalah bukan sesuatu yang innate, alami atau mengandung keabadian tetapi sesuatu yang dikonstruksikan oleh lingkungan sosial. Kubu lain percaya mengenai keberadaan moral absolut yang semakin berperan dalam pendidikan karakter. Kubu ini disebut sebagai kelompok konservatif yang percaya bahwa ada standar moral yang berlaku umum yakni standar yang berlaku absolut, universal, di mana agama dan budaya pasti mengakuinya (Megawangi, 2004).

Pemahaman konsep dan strategi pengembangan karakter seyogyanya dilihat dari filosofi ideografis dan nomotetis. Filosofi ideografis merujuk kepada kemampuan individual, sedang filosofi nomotetis merujuk pada internalisasi nilai-nilai filsafat pendidikan Indonesia yakni Pancasila. Selama ini pendidikan di Indonesia fokus pada filosofi ideografis, sementara filosofi nomotetis hampir terabaikan. Akibatnya kehidupan berbangsa semakin rapuh, karena tujuan utama mereka adalah hanya untuk memperkaya diri sendiri. Ketika sedang menduduki posisi di pemerintahan yang dipikirkan adalah untuk memperkaya diri sendiri. Kehilangan filosofi nomotetis dari kehidupan berbangsa merusak pembangunan karakter Pancasila. Nilai Pancasila adalah acuan konsep, implementasi serta tujuan yang harus dicapai dalam kehidupan berbangsa (Manullang, 2013).

Dalam menunjang implementasi tersebut, pendidikan umum merupakan salah satu metode untuk mengimplementasikan pendidikan karakter secara nyata. Oleh sebab, pendidikan umum merupakan hati nurani dari pendidikan (Miller, 1988). Akan tetapi, Pendidikan Umum di Indonesia belum memiliki jati diri yang tangguh, oleh sebab pelaksanaan Pendidikan Umum masih menyerahkan pengembangannya kepada universitas (Miller, 1998). Selain itu, masih terdapat tumpang tindih antara ranah Pendidikan Umum dengan ranah disiplin ilmu lainnya seperti Pendidikan Agama dan Pendidikan Kewarganegaraan. Hal tersebut dapat dilihat dari berbagai hasil penelitian yang tidak jelas membagi dimana eksistensi setiap disiplin ilmu dalam penelitian tersebut.

Proses pengokohan espistemologi Pendidikan Umum di Indonesia sebagai pendidikan disiplin ilmu terdapat dalam beberapa karya disertasi yang telah diteliti. Namun, secara utuh di dunia, pengokohan Pendidikan Umum telah berjalan sangat lama. Adapun mata kuliah Pendidikan Umum yang dibelajarkan di perguruan tinggi meliputi Pendidikan Agama, Pendidikan Kewarganegaraan, Pendidikan Pancasila, dan Pendidikan Bahasa Indonesia. Hal tersebut menurut Howard (1992) dilakukan untuk menyelamatkan perguruan tinggi dengan memberi fasilitas interaksi komunikatif melalui perkuliahan mata kuliah wajib yang tidak hanya memandang pendidikan umum sebagai proses menanamkan generasi masa depan dengan nilai-nilai, kepercayaan, dan praktik-praktik masyarakat dengan metode komunikatif. Oleh sebab, apabila konteks pendidikan karakter dalam pendidikan umum disajikan sebagai nilai-nilai kebenaran 
yang sudah diterima, alih-alih sebagai perjuangan dengan pertanyaanpertanyaan abadi tentang keberadaan manusia, mereka yang dianugerahi kebenaran seperti itu tentu akan menjadi 'buta huruf', mereka tidak akan dapat membaca tanda-tanda dan simbol-simbol zaman mereka. Untuk menghindari hal tersebut, maka beberapa perguruan tinggi mengadakan kegiatan lain selain kegiatan rutin seperti yang dilaksanakan di Universitas Pendidikan Indonesia seperti program tutorial juga dilaksanakan melalui program insidental.

Dalam praktik demikian, program pendidikan umum lebih dekat dengan Essensialis dan pragmatis (Howard, 1992) yang harus selalu memperhatikan dan memperhitungkan konteks sosial berupa reformasi kurikuler yang lebih besar (Husserl, 1965). Bagi kaum Esensialis, terdapat standar objektif untuk kebenaran yang dapat diakses oleh akal manusia. Kapasitas untuk bernalar dapat dikembangkan dan difasilitasi melalui latihan pemahaman yang tepat. Esensialisme juga mirip dengan Idealisme sejauh Esensialis melihat akhir manusia dalam pengembangan penuh kekuatan intelektual, meskipun untuk Hutchins yang tidak dapat membentuk kebiasaan mental yang sejalan dengan metafisika Aristoteles dan Aquinas. Gagasan bahwa terdapat pendidikan khusus untuk pendidikan terbaik adalah khusus untuk program Essentialism dan the Great Books (Howard, 1992). Sementara dalam konteks Pragmatisme, universitas yang dijelaskan Kerr adalah universitas yang sekarang berada dalam proses mengatasi masalah reformasi kurikuler; universitas yang lebih mekanisme daripada organisme, pluralisme dan monisme, dan secara sah terhubung dengan urusan duniawi bisnis dan pemerintah (Kerr, 1982). Hal tersebut menjadi masalah, sebab pendidikan umum yang harusnya mendidik pendidikan karakter kemudian menjadi masalah administrasi, alokasi tugas mengajar, penerapan kredit semester (pengembangan dari Howard, 1992). Hal tersebut nampak jelas pada setiap perguruan tinggi yang diteliti.

Apabila pendidikan umum berfungsi sebagai latar belakang konsensus untuk kurikulum sarjana, kurikulum sarjana berfungsi, secara memadai atau tidak memadai, sebagai ekspresi tertinggi dari latar belakang konsensus masyarakat dominan yang mendukungnya. Ketika gagal dalam misi itu, legitimasi universitas itu sendiri dipertanyakan. Ini bukan untuk mengatakan bahwa latar belakang konsensus yang disediakan oleh kurikulum sarjana dibagi oleh semua kepentingan yang beragam dari komunitas universitas itu sendiri, tetapi pemahaman semacam itu dibagi sampai batas tertentu oleh kepentingan yang melayani dan dilayani oleh universitas. Pendidikan umum, paling tidak secara potensial, membawa ke dalam bidang pemikiran alasan kritis elemen-elemen kesadaran individu dan kolektif yang belum diteliti yang membentuk, melalui penerapan sehari-hari, jalinan kehidupan budaya kita (Howawrd, 1992)

Dalam konteks perkembangan sosial, kebenaran sering diukur dengan instrumen sains. Padahal menurut Husserl sebagian besar sains telah kehilangan signifikansinya bagi kehidupan manusia karena ia tidak dapat mempertahankan hubungan antara kebenaran sains dan kebenaran 'kehidupan praktis'. Dunia sains, walaupun penuh dengan kebenaran karakter yang absolut dan abadi, tidak dapat menyapa manusia dalam diri manusia 'Lebenswell' (atau dunia kehidupan) karena perspektif sains adalah obyektif dan bebas nilai sedangkan perspektif manusia adalah subjektif dan sarat nilai. Hasilnya adalah hubungan yang tidak pasti antara aktivitas ilmiah manusia dan aktivitas manusia dalam mengejar kepentingan praktis. Ini juga menghasilkan devaluasi ranah manusiasubyektif karena ranah itu tidak dapat 
menghasilkan pengetahuan nomologis (Howard, 1992)

Selain itu, pendekatan Idealis untuk pendidikan umum adalah melakukan asumsi epistemologis mengenai kebenaran dan kondisi untuk validasinya. Sumbernya adalah trancendental, atau setidaknya di luar cengkeraman duniawi dan kondisi untuk validasinya cenderung didasarkan pada koherensi yang ideal. Koherensi logis adalah penengah akhir dari proposisi untuk kaum Idealis, dan tidak tergantung pada penilaian manusia sejauh itu merupakan syarat untuk penilaian manusia (Howard, 1992)

Dari sudut pandang teori kritis, sains 'bebas nilai' itu sendiri merupakan produk dari suatu nilai: kontrol dan dominasi dunia alami (Horkheimer, 1972 dan 1974). Keberhasilan sains modern dan khususnya teknologi modern, dalam pandangan para pemikir Frankfurt School seperti Hoerkeimer (1972) cenderung membanjiri akal manusia dengan kemungkinan penguasaan alam yang tidak tertandingi. Itulah kekuatan alasan instrumental yang dapat memadamkan alasan kritis, dan karenanya menjadikan dirinya sebagai standar tunggal untuk rasionalitas.

Teori kritis bercita-cita untuk membawa subjek sendiri ke kesadaran diri penuh dari kontradiksi yang tersirat dalam keberadaan material mereka, untuk menembus mistifikasi ideologis dan bentuk-bentuk kesadaran palsu yang menghancurkan makna kondisi sosial yang ada. Ahli teori kritis melihat perbedaan antara teori dan tindakan yang diterima oleh pendukung teori tradisional, sebagai dirinya sendiri dan refleksi ideologis dari masyarakat di mana 'teori' hanya berfungsi untuk menumbuhkan status quo (Bernstein, 1978).

Dalam pengetahuan dan kepentingan manusia (1971), Habermas berusaha untuk membumikan teori kritis sosial dalam kepentingan kognitif manusia. Penting untuk dicatat bahwa
Hubermas tidak merendahkan klaim pengetahuan dari setiap kepentingan manusia. Dia hanya berargumen bahwa klaim sains analitik empiris bukan satusatunya klaim yang memiliki legitimasi, dan bahwa mereka tidak boleh dianggap sebagai model untuk semua jenis pengetahuan lainnya. Perbedaan antara apa yang ia sebut aksi atau interaksi 'purposive-rasional' dan interaksi atau 'aksi komunikatif' adalah yang kritis. Klaim sains analitik-empiris divalidasi melalui metode ilmiah dan semua aturan teknis yang menyiratkan metode ilmiah, sementara klaim sains hermeneutik historis divalidasi melalui kesepakatan konsensus norma intersubjektif. Kritik terhadap pengetahuan membutuhkan tematisasi kepentingan yang mendasari berbagai bentuk penyelidikan, kritik terhadap kesadaran moral-praktis menuntut menanyakan apa yang harus kita ketahui, dan ini bergantung pada apa yang bisa kita ketahui. Alasan teoretis dan praktis terkait erat; mereka adalah momen-momen rasionalitas komprehensif yang perkembangannya koheren menandakan perkembangan kehendak rasional (McCarthy, 1978)

Dengan demikian, implementasi pendidikan karakter dalam konteks pendidikan umum menurut kacamata teori kritis Jurgen Hubermas harus mengikuti beberapa prinsip dari jumlah 14 (empat belas) antara lain (1) terdapat hubungan epistemologis yang tidak terhindarkan antara pengetahuan dan kepentingan manusia, antara fakta dan nilai, antara praktik dan teori; (2) teori kritis memiliki kepentingan mendasar dalam membawa pada kesadaran eksplisit ketegangan antara apa yang seharusnya; (3) ilmu analitik empiris hanyalah salah satu cara untuk menghubungkan kepentingan manusia dengan pengetahuan; dan (4) kebenaran suatu pernyataan tergantung pada kesepakatan potensial dari semua yang lain.

Teori kritis pendidikan umum didasarkan pada proses komunikatif itu 
sendiri. Dengan menerapkan teori Habermas tentang kompetensi komunikatif pada proses komunikatif yang mengartikulasikan pendidikan umum, dimungkinkan untuk secara filosofis melampaui ideologis langsung yang dapat dinilai oleh program-program semacam itu. Ada tiga aplikasi tingkat untuk teori Habermas: tingkat awal konseptualisasi dan perencanaan, di mana program generasi tertentu diartikulasikan; tingkat implementasi dan pemeliharaan melalui mana rencana pendidikan umum adalah dan disesuaikan dengan keadaan kehidupan akademik yang tidak terduga; dan tingkat pedagogis di mana program disampaikan siswa di kelas. Teori kompetensi komunikatif berlaku untuk ketiga level aplikasi dan sejauh mana komunikasi di ketiga level tersebut memenuhi kriteria teori Habermas 'mengukur sejauh mana program yang disusun dengan demikian adalah sah (Howard, 1992)

Sifat sangat kritis dari teori kompetensi komunikatif Habermas mungkin dapat dilihat dengan menyempurnakan analogi antara psikoanalisis dan kritik. Dalam Pengetahuan dan Kepentingan Manusia (1971), Habermas menarik analogi yang sangat selektif antara teori kritis dan psikoanalisis di mana ia berusaha menunjukkan bahwa tujuan masingmasing adalah pemahaman diri melalui refleksi diri. Psikoanalis berusaha tidak hanya untuk menembus pemahaman diri pasien, tetapi juga untuk menggerakkan pasien untuk mengingat kembali dan merekonstruksi pemahaman dirinya sendiri. Analis ini tidak dapat melakukan untuk pasien seperti halnya pasien dapat melakukannya untuk dirinya sendiri dengan menghadiri kuliah dan membaca buku tentang psikoanalisis. Tidak cukup untuk menggambarkan pemahaman diri yang terdistorsi, pasien harus menginternalisasi wawasan dengan melembagakan dan melanggengkan proses refleksi diri. Pasien 'sembuh' sejauh ia mempertahankan kebiasaan refleksi diri seperti itu dan membawanya melalui pengalaman masa depannya. Tujuan dari analogi ini adalah untuk menunjukkan bagaimana kritik terhadap ideologi tergantung pada proses refleksi diri semacam itu. Analogi yang sama berlaku untuk pendidikan umum di ketiga tingkatan aplikasi.

Dalam analisis akhir, sebagaimana dikatakan Habermas, kondisi untuk wacana ideal identik dengan kondisi untuk bentuk kehidupan ideal, dan kondisi untuk reformasi kurikuler ideal identik dengan kondisi untuk pengajaran dan pembelajaran yang efektif dalam konteks pendidikan umum, mereka termasuk konseptualisasi linguistik dari ide-ide tradisional kebebasan dan keadilan. "Kebenaran," karena itu, tidak dapat dianalisis secara independen dari "kebebasan" dan "keadilan" (Habermas, 1975). Dengan kata lain, komite artikulasi harus menciptakan di antara mereka sendiri lingkungan yang mereka harapkan untuk diperluas ke seluruh universitas - jika mereka tidak dapat melakukan itu, proyek reformasi pasti akan gagal. Mungkin ada orang-orang di komite ini yang menginginkannya gagal, dan jika itu masalahnya, mereka harus dikonversi atau dinetralkan oleh kekuatan konsensus rasional.

Hal yang harus diingat, mahasiswa bukan sekadar wadah pasif tempat deposito dibuat untuk penarikan di kemudian hari. Pikiran mereka juga bukan semacam otot yang membutuhkan disiplin dan pelatihan. Para siswa memiliki martabat yang melekat, mereka memiliki hak yang sama dengan tindakan berbicara bebas seperti peserta lain dalam wacana komunikatif, dan mereka sering memberikan kontribusi penting untuk proses pembentukan kehendak diskursif. Karena setiap generasi harus menegaskan kembali hubungan dengan yang benar dan adil, dan karena setiap generasi mahasiswa tampaknya lebih heterogen 
daripada yang terakhir, pendidikan umum harus dilihat sebagai kontribusi yang berharga untuk proses ini (Howard, 1992).

\section{SIMPULAN DAN SARAN \\ Simpulan}

Implementasi pendidikan karakter dalam konteks pendidikan umum masih mengalami kendala dalam pelaksanaannya. Sebab pendidikan umum sebagai hati nuraninya pendidikan untuk mengarahkan pendidikan pada nilai-nilai karakter, tetapi perguruan tinggi mengalami beberapa kendala seperti masih kurang dipahaminya kebijakan pendidikan karakter yang harus berbuah budaya-budaya institusi dan kurangnya pendidikan berkelanjutan tentang pendidikan karakter bahkan cenderung adminstratif. Namun demikian, dalam pandangan teori kritis yang dikemukakan oleh Jurgen Hubermas, memaksakan sesuatu nilai dengan tanpa menghargai eksistensi mahasiswa sebagai manusia bermartabat akan membuat mereka "buta huruf' terhadap masa depan mereka. Oleh sebab itu, mereka harus diberikan pelatihan dan penguatan dengan memberikan pendidikan umum yang bermartabat agar arah pendidikan karakter memberikan pengembangan sesuai dengan kemampuan mahasiswa dan lebih manusiawi dengan harapan mereka dapat menjawab apa yang seharusnya mereka lakukan dengan konteks yang dihadapi.

\section{Saran}

Pendidikan karakter dalam konteks pendidikan umum ditinjau dari teori kritis seharusnya bukan terikat dengan nilai-nilai baku yang sudah dikembangkan melainkan menyesuaikan dengan apa yang seharusnya mahasiswa peroleh untuk menghadapi masa depan mereka.

\section{DAFTAR RUJUKAN}

Aloi, S.L.,Gardner, W.S.,Lusher, A.L. (2003). A Framework for Assesing General Education
Outcomes within The Majors. The Journal of General Education. 52 (4), 237-252

Awbrey, S. M. (2005). General Education Reform as Organizational Change: Integrating Cultural and Structural Change. The Journal of General Education. 54 (1), 1-21.

Azra, A. (2001). Pendidikan Akhak dan Budi Pekerti: Membangun Kembali Moral Bangsa. Makalah dalam Buletin Mimbar Pendidikan, UPI Bandung No 1 tahun XXX.

Bahrun. (2012). Kajian Fenomenologis tentang Pola Pendidikan Karakter melalui Sistem "Fullday School" pada SMA Labschool Universitas Syiah Kuala. Disertasi pada Program Studi Pendidikan Umum SPs UPI. Tidak diterbitkan.

Bernstein, R. J. (1978). The Restructuring of Social and Political Theory. University Pennsylvania Press.

Budimansyah, D. (2009). Membangun Karakter Bangsa Di Tengah Arus Globalisasi dan Gerakan Demokratisasi (Pidato Pengukuhan Guru Besar Bidang Sosiologi Kewarganegaraan). Bandung: Program Studi Pendidikan Kewarganegaraan SPs UPI.

Budimansyah, D. (2010). Penguatan Pendidikan Kewarganegaraan untuk Membangun Karakter Bangsa. Bandung: Widya Aksara Press

Creswell, J.W. (1994). Research Design Qualitative \& Quantitative Approach. London: Publication.

Direktorat Ketenagaan, Direktorat Jenderal Pendidikan Tinggi. (2010). Kerangka Acuan Pedidikan Karakter Tahun Anggaran 2010. Jakarta: Kementerian Pendidikan Nasional 
Habermas, J. (1971). Knowledge and Human Interests trans. By Jeremy J. Shapiro. Boston: Beacon Press.

Habermas, J. (1975). Legitimation Crisis trans. By Thomas McCarthy. Boston: Beacon Press.

Hokheimer, M. (1972). Critical Theory trans. By Matthew J. O'Conneli et.al. New York: Seabury Press.

Hokheimer, M. (1974). Critique of Instrumental Reason trans. By Matthew J. O'Conneli et.al. New York: Seabury Press.

Howard, C.C. (1992). Theories of General Education: A Critical Approach. Newyork: St. Martin's Press.

Husserl, E. (1965). Phenomenology and the Crisis of Philosophy trans. By Quent Lauer. New York: Harper \& Row.

Jencks, C., \& Riesman, D. (1968). The academic revolution. New York: Doubleday.

Kaimudin. (2014). Implementasi Pendidikan Karakter dalam Kurikulum 2013. Dinamika Ilmu. 14 (1), 47-64.

Kerr, C. (1982). The Uses of The University $3^{\text {rd }}$ edn. Cambridge, Mass: Harvad University Press.

Manullang, B. (2013). Grand Desain Pendidikan Karakter Generasi Emas 2045. Jurnal Pendidikan Karakter. 3 (1), 1-14

McCarthy, T. (1978). The Critical Theory of Jurgen Habermas. Cambrigge. Ma and London: M.I.T. Press.

Megawangi, R. (2004) Pendidikan Karakter (Solusi yang Tepat untuk Membangun Bangsa. Bandung: (Sponsor) BPMIGAS dan Energy.
Miller, G. E. 1988. The meaning of general education: The emergence of a curriculum paradigm. New York: Teachers College Press.

Pemerintah Republik Indonesia. (2010). Kebijakan Nasional

Pembangunan Karakter Bangsa Tahun 2010-2025. Jakarta: Pemerintah Republik Indonesia.

Raka, G.,dkk. (2011). Pendidikan Karakter di Sekolah: Dari Gagasan ke Tindakan. Jakarta: PT. Gramedia.

Sudarminta SJ. 1997. Etika Umum. Kajian tentang Beberapa Masalah Pokok dan Teori Etika Normatif. Jakarta : Sekolah Tinggi Filsafat Driyakarya Sudarminta SJ. 1997. Etika Umum. Kajian tentang Beberapa Masalah Pokok dan Teori Etika Normatif. Jakarta: Sekolah Tinggi Filsafat Driyakarya

TIM PPK Kemendikbud. (2017). Modul Pelatihan Penguatan Pendidikan Karakter Bagi Komite Sekolah. Jakarta: Pusat Analisis dan Sinkronisasi Kebijakan Sekretariat Jenderal Kementerian Pendidikan dan Kebudayaan.

Undang-Undang Dasar Negara Republik Indonesia Tahun 1945

Undang-Undang Republik Indonesia Nomor 17 Tahun 2007

Zuriah, N. (2007). Pendidikan Moral dan Budi Pekerti dalam Perspektif Perubahan. Jakarta: Bumi Aksara. 